
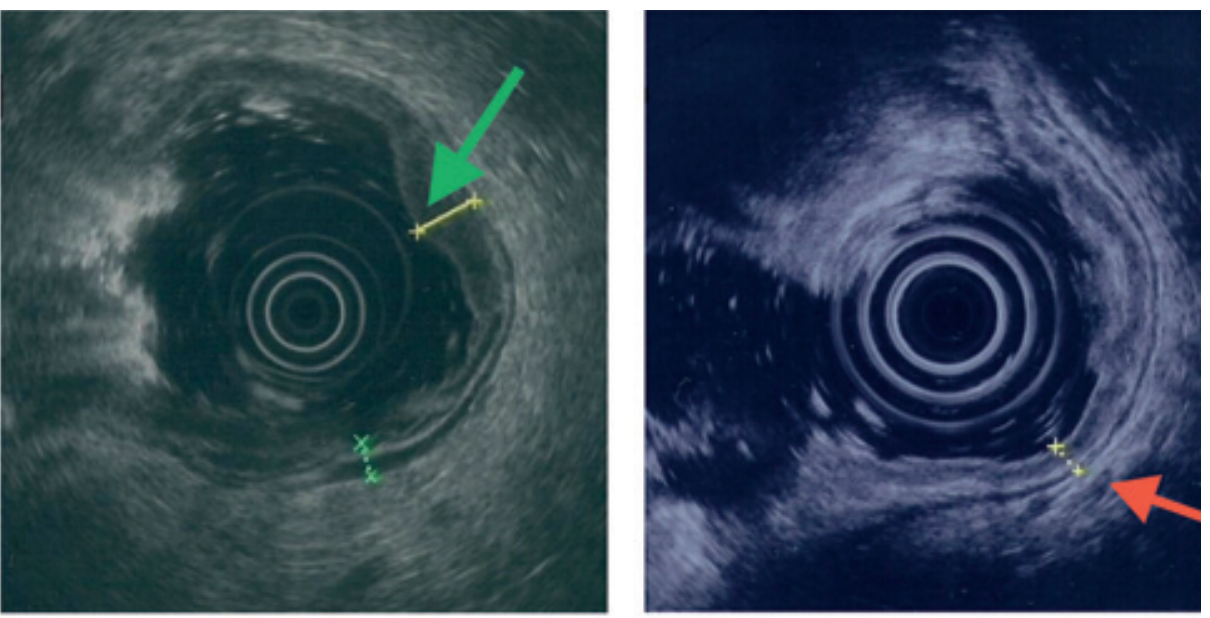
a

b

Figur 3 Endoskopisk ultralyd tatt a) 14 dager etter oppstart av antiviral behandling viser fortsatt fortykket ventrikkelslimhinne (grønn pill. b) Etter tre måneder er det tilnærmet normalisering av ventrikkelslimhinnens tykkelse (rød pil)

Hos immunsupprimerte er viruset vanligere som sykdomsfremkallende agens, både som primærinfeksjon og ved reaktivering av latent virus.

Diagnostisering av viruset i gastrointestinaltractus er vanskelig. To serologiske prøver med noe tidsavstand kan hjelpe til med å skille primærinfeksjon og reaktivering. Tilstedeværelse av spesifikt IgM alene kan ikke skille mellom primærinfeksjon og reaktivering. Senere serokonvertering med fallende IgM-nivå og signifikant stigning i IgGnivå taler for primærinfeksjon. Ved hjelp av PCR-teknikk kan man påvise virus både $i$ slimhinner og i avføring. Påvisning i små mengder uten slimhinneforandringer har usikker betydning. Ved tydelig slimhinneaffeksjon kombinert med histologiske funn av inklusjonslegemer i nukleus og cytoplasma i infiserte celler og positiv immunhistokjemisk farging med antistoff mot cytomegalovirus er aktuell infeksjon sannsynlig. Cytomegalovirusinfeksjoner er beskrevet $\mathrm{i}$ hele gastrointestinaltractus. Viruset kan gi hele spekteret av infeksjoner - fra enkle, asymptomatiske gastritter til alvorlige kolitter (5).

Etter søk i PubMed med «cytomegalovirus» og «Ménétrier» finner vi flere rapporter om en reversibel Ménétrier-liknende tilstand assosiert med cytomegalovirus hos barn (6, $7)$. Det finnes også noen svært få rapporter om en tilsvarende tilstand hos voksne, i de fleste tilfeller hos immunsupprimerte, men et liknende sykdomsbilde er også rapportert hos immunkompetente voksne. Hos flere er det forsøkt antiviral behandling, med god effekt. Spontan bedring uten behandling er også beskrevet (7-9).

Hyperplastiske ventrikkelslimhinner påvist ved endoskopi er et uspesifikt funn. Endoskopisk er det vanskelig å skille klassisk Ménétriers sykdom fra andre tilstander som gir liknende bilde. Transabdominal og endoskopisk ultralyd gir ofte en god fremstilling av slimhinnen i ventrikkelen og er et nyttig supplement (10).

Hos vår pasient ga endoskopi kombinert med transabdominal og endoskopisk ultralyd god fremstilling av en hyperplastisk gastropati. Det kliniske bildet pekte i retning av Ménétriers sykdom. Ved histologisk undersøkelse var epitelhyperplasien moderat. Veggfortykkelsen var mer dominert av betennelsesceller enn av foveolar slimhinnehyperplasi, som er typisk for Ménétriers sykdom. Histologien kunne tale i retning av infeksiøse forandringer. På grunnlag av supplerende etiologiske undersøkelser og sykdommens forløp etter behandling velger vi å gi vår pasient diagnosen reversibel cytomegalovirusindusert Ménétriers sykdom. Det er få rapporter om tilstanden hos voksne, flere hos barn. Det histologiske bildet samt sykdommens forløp i vårt tilfelle gjør at vi ikke kan definere dette som klassisk Ménétriers sykdom.

Pasienten har gitt samtykke til at artikkelen blir publisert.

\section{Oppgitte interessekonflikter: Ingen}

\section{Litteratur}

1. Ménétrier PE. Des polyadenomatoses gastriques et leurs rapport avec le cancer de l'estomac. Arch Physio Norm Pathol 1888; 32: 236.

2. Yardley J, Hendrix T. Hyperplastic gastropathies and other causes of enlarged gastric folds. Uptodate online 16.3. April 2006. http://utdol.com/ online/content/topic.do?topicKey=acidpep/9331 (4.2.2010).

3. Meuwissen S, Ridwan B, Hasper H et al. Hyper trophic protein-loosing gastropathy. A retrospective analysis of 40 cases in the Netherlands. The Dutch Ménétrier Study Group. Scand J Gastroenterol Suppl 1992; 194: 1-7.

4. Bayerdorffer E, Ritter M, Hatz R et al. Healing of protein losing hypertrophic gastropathy by eradication of Helicobacter pylori - is Helicobacter pylori a pathogenic factor in Ménétrier disease? Gut 1994; 35: $701-4$

5. Moum B, Aukrust P, Bjørneklett A et al. Cytomegalovirussykdom I gastrointestinaltractus. Tidsskr Nor Lægeforen 1991; 111: 3388-91.

6. Sferra T, Pawel B, Qualman S et al. Ménétrier disease of childhood: role of cytomegalovirus and transforming growth factor alpha. J Pediatr 1996 : 128: $213-9$

7. Xiao SY, Hart J. Marked gastric foveolar hyperplasia associated with active cytomegalovirus infection. Am J Gastroenterol. 2001: 96: 223-6.

8. Pinho V, Ibrahim A, Avila Garavito A et al. Proteinlosing gastropathy associated with cytomegalovirus: a rare complication of allogenic bone marrow transplantation. Bone Marrow Transplant 1996; 17: 887-9.

9. Suter W, Neuweiler J, Borovicka J et al. Cytomegalovirus-induced transient protein-losing hypertophic gastropathy in an immuncompetent adult. Digestion 2000; 62: 276-9

10. Gilja $\mathrm{OH}$. Ultrasound of the stomach - EUROSON lecture 2006. Ultraschall Med 2007; 28: 32-9.

Manuskriptet ble mottatt 18.6. 2009 og godkjent 4.2. 2010. Medisinsk redaktør Siri Lunde.

\title{
Et uvanlig proteintap i tarm
}

Engjom og medarbeidere beskriver en grundig og reflektert utredning av en ung mann med ødemer, der resultatet viste seg overraskende. Selv om tilstanden mannen led av ikke er dagligdags medisin, utgjøres de «sjeldne tilfeller» av helt ordinære pasienter. Kun en systematisk tilnærming med god kunnskap om patofysiologi kan føre til en sikker diagnose.

I teorien kan en rekke tilstander føre til hypoalbuminemi, men flere av disse syntes helt uaktuelle (sepsis, brannskader, alvorlig underernæring m.m.). I fravær av slike åpenbare og/eller akutte mekanismer er det riktig å vurdere manglende syntese av proteiner $\mathrm{i}$ lever eller tap i nyrer. INR-verdi nær referanseområdet samt normale nivåer av leverenzymer og bilirubin gjorde leversykdommer usannsynlig. Ultralyd av lever bekreftet normalt organ, og man fant ikke alvorlig proteinuri. Ved gastroskopi fant man grove 
folder $\mathrm{i}$ ventrikkelslimhinnen $\mathrm{i}$ corpus og fundus. Det endoskopiske bildet gjorde at man tenkte på Ménetriérs sykdom, men biopsier viste at det heller forelå sannsynlig cytomegalovirussykdom. Dette endoskopiske og histologiske bildet er sjeldent. Infeksjon med cytomegalovirus kan gi en rekke manifestasjoner (1). Større sykdom er sjelden hos immunkompetente, men ses ofte hos immunsupprimerte. Som kjent er mange av oss bærere av virus uten at primærinfeksjonen er blitt klinisk erkjent annet enn som en litt langvarig feberepisode. Den beskrevne pasienten kan meget vel ha hatt en cytomegalovirusinfeksjon i ukene frem til han ble innlagt.

Selv om presentasjonen er god, er det noen få aspekter som ikke diskuteres. En åpenbar årsak til proteintapende tarm, intestinal lymfangiektasi, er ikke omtalt. Denne sykdommen kan være både primær og sekundær og kan meget vel debutere i voksen alder. Gastroskopi med inspeksjon av både ventrikkel og duodenum er viktig, og man må bekrefte et uvanlig endoskopifunn i duodenum med biopsier. Hos pasienten var nivået av immunglobuliner bare lett nedsatt, det passer dårligere med intestinal lymfangiektasi.
Det anføres i artikkelen at det ikke finnes gode metoder for å anslå proteininnhold $\mathrm{i}$ avføring. Det er vel bare delvis riktig. Oslo universitetssykehus, Rikshospitalet har brukt nukleærmedisinsk metode for å fastslå proteintap i tarm. Selv om metoden ikke er kvantitativ, kan man allikevel få et inntrykk av lokalisasjon og intensitet. Det er i litteraturen også beskrevet måling av $\alpha_{1}$-antitrypsin i avføring som et relativt godt mål på proteintap, i hvert fall når 24-timers avføring samles og sammenliknes med plasmanivå (2). Så vidt jeg vet, er ikke testen tilgjengelig i Norge.

Kasuistikken beskriver meget godt aspektene rundt de såkalte hyperplastiske gastropatier (3). Begrepet Ménétriers sykdom brukes av mange som synonymt med forstørrede folder, men det er ikke riktig. Ultralyd og endoskopi kan gi god informasjon om tykkelsen av slimhinnen, men ikke om det histologiske bildet. Ved Ménétriers sykdom ser man foveolær hyperplasi med slimproduksjon, mens den oksyntiske (syreproduserende) mucosa er normal aller atrofisk. Derimot finner man hyperplasi av parietalceller ved Zollinger-Ellisons syndrom. Blandingsformer, med hyperplasi av både mukøs og oksyntisk slimhinne, ses ved kronisk gastritt forårsaket av Helicobacter pylori og andre infeksiøse agenser som for eksempel (i sjeldne tilfeller) cytomegalovirus. Det er derfor ikke helt korrekt, etter mitt syn, å gi diagnosen «reversibel cytomegalovirusindusert Ménétriers sykdom». Man burde nok heller brukt en deskriptiv beskrivelse som «cytomegalovirusindusert gastropati».

\section{Knut Lundin}

k.e.a.lundin@medisin.uio.no

Seksjon for fordøyelsessykdommer

Oslo universitetssykehus, Rikshospitalet 0027 Oslo

Oppgitte interessekonflikter: Ingen

\section{Litteratur}

1. Moum B, Aukrust P, Bjørneklett A et al. Tidsskr Nor Lægeforen 1991; 111: 3388-91.

2. Strygler B, Nicor MJ, Santangelo WC et al. Alpha 1 -antitrypsin excretion in stool in normal subjects and in patients with gastrointestinal disorders. Gastroenterology 1990; 99: 1380-7.

3. Cotran RS, Kumar V Robbins SL Robbins' pathological basis of disease. 4. utg. Philadelphia, PA: Saunders, 1989

Manuskriptet ble mottatt 14.6. 2010 og godkjent 24.6. 2010. Medisinsk redaktør Siri Lunde. 